J, Ottinger J, Lamoreaux L, Epling CL, Sinclair E, Suni MA, Punt K, Calarota S, El-Bahi S, Alter G, Maila H, Kuta E, Cox J, Gray C, Altfeld M, Nougarede N, Boyer J, Tussey L, Tobery T, Bredt B, Roederer M, Koup R, Maino VC, Weinhold K, Pantaleo G, Gilmour J, Horton H, Sekaly RP. Standardization of cytokine flow cytometry assays. BMC Immunol 2005;6:13.
5. Nascimbeni M, Shin EC, Chiriboga L, Kleiner DE, Rehermann B. Peripheral CD4+ CD8+ T cells are differentiated effector memory cells with antiviral functions. Blood 2004;104:478-486.

6. Sullivan $Y B$, Landay $A L$, Zack JA, Kitchen SG, Al-Harthi L. Upregulation of CD4 on $C D 8^{+} T$ cells: $C D 4^{\text {dim }} C D 8^{\text {bright }} T$ cells constitute an activated phenotype of CD8+ T cells. Immunology 2001;103:270-280.

\title{
A Novel Mutation in a Patient with Wiskott-Aldrich Syndrome
}

\section{Wiskott-Aldrich Sendrom'lu Bir Hastada Yeni Bir Mutasyon}

\author{
(D) Yurday Öncül1, (D) Arzu Akyay¹, (D) ibrahim Tekedereli2 \\ 1 Inönü University Faculty of Medicine, Division of Pediatric Hematology, Malatya, Turkey \\ 2inönü University Faculty of Medicine, Division of Medical Genetics, Malatya, Turkey
}

\section{To the Editor,}

We read with great interest the recently published article in your journal by Kaya et al. [1] regarding a novel mutation in the Wiskott-Aldrich syndrome (WAS) gene. After that publication, we also had a patient with another novel mutation in the WAS gene from Turkey.

A 3-month-old boy was admitted to our hospital with the complaints of cough, wheezing, and eczema. He also had a history of pneumonia. On physical examination, diffuse eczema was observed (Figure 1), along with widespread petechiae and pulmonary crepitant rales and rhonchi. His family history was unremarkable. Laboratory analysis revealed anemia (hemoglobin of $8.9 \mathrm{~g} / \mathrm{dL}$ ), leukocytosis (white blood count of $13,330 / \mathrm{mm}^{3}$ ), and thrombocytopenia (platelet count of $63,000 / \mathrm{mm}^{3}$ ). Mean platelet volume was $4.8 \mathrm{fL}$. A peripheral blood smear revealed thrombocytopenia and micro-thrombocytes. Immunoglobulin levels were normal. Peripheral lymphocyte subset analysis revealed reduced CD3 percentage and CD16/CD56 ratio. With these results, patient was diagnosed with WAS, and molecular genetic analysis revealed a novel mutation in the WAS gene, a hemizygous c.11_12insGG p.G4Afs mutation on exon 1 (Figure 2). The patient is 18 months old now. Human intravenous immunoglobulin therapy was administered monthly, and thrombocyte replacement was done in case of need [2]. He did not have a family donor, so he was scheduled for allogeneic hematopoietic stem cell transplantation from an unrelated donor.

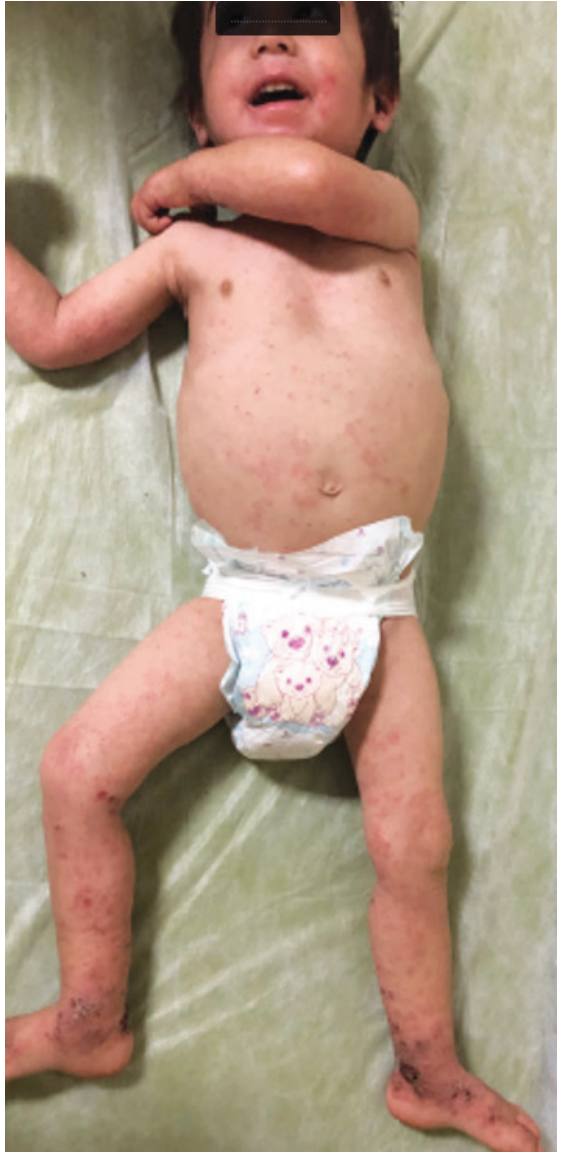

Figure 1. Physical examination revealed diffuse eczema, widespread petechiae, and pulmonary crepitant rales and rhonchi. 


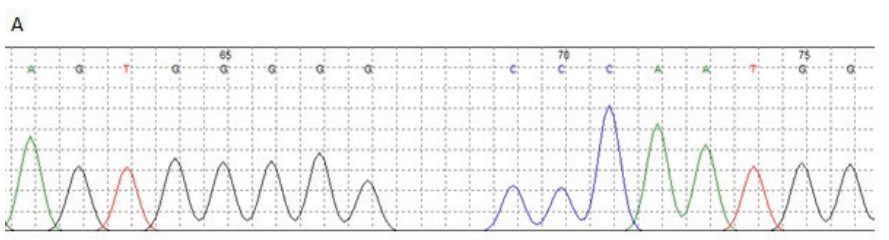

B

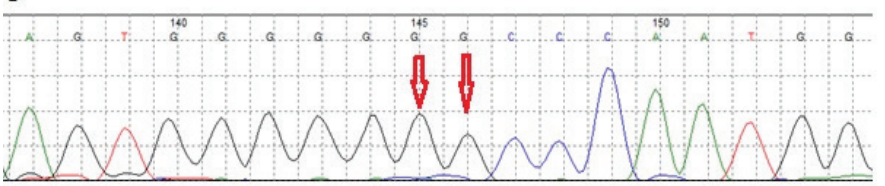

Figure 2. Hemizygous c.11_12insGG p.G4Afs mutation on exon $1(A, B)$.

The clinical presentation of WAS is very heterogeneous. Based on the severity of symptoms, a 5-point severity score was developed [2,3]. This score differentiates patients with milder presentation (scores of up to 2) from the severe classic WAS phenotype (scores of 3-5). While most patients suffer from thrombocytopenia and susceptibility to infections, the other clinical complications of the disease can be variably present [4]. WAS cases with milder clinical manifestations are usually referred to as X-linked thrombocytopenia (XLT) [4,5]. XLT patients must also be carefully monitored, however, because patients with initially mild phenotypes can transition to severe phenotypes. Our patient presented a classical severe case of WAS with severe eczema, immune deficiency with recurrent infections, and thrombocytopenia.

There are many possible mutations in the WAS gene. However, missense mutations are seen most often, especially on the first four exons. The subsequently most frequent mutations are splice mutations, deletions, insertions, nonsense mutations, and complex mutations in descending order $[3,4]$. The missense mutations on exons 2 and 3 are linked to mild phenotypes [5]. The nonsense mutations, insertions, and deletions are often associated with severe phenotypes. In our case, a hemizygous c.11_12insGG p.G4Afs mutation on exon 1 was detected. This was a frameshift mutation. Frameshift mutations encode incorrect amino acids and usually cause nonsense codons [6]. Another frameshift mutation at the c:11 position on the WAS gene with deletion of a guanine nucleotide has been reported as a disease-causing variant [7]. In our case, an insertion affected the WAS protein and led to the emergence of the disease. Therefore, the $11^{\text {th }}$ position on WAS cDNA could be referred to as a mutational hotspot. To the best of our knowledge, this is the first case of this mutation to be presented. We suspect that this mutation might be important in contributing to the genotypephenotype relation.

Keywords: Wiskott-Aldrich Syndrome, WAS gene, Novel mutation

Anahtar Sözcükler: Wiskott-Aldrich sendromu, WAS geni, Yeni mutation

Informed Consent: Written informed consent was received from the patient's parents.

\section{Authorship Contributions}

Concept: A.A., Y.Ö.; Data Collection or Processing: Y.Ö., A.A.; Analysis or Interpretation: A.A., Y.Ö., I.T.; Literature Search: Y.Ö. A.A., I.T.; Writing: Y.Ö., A.A., I.T.

Conflict of Interest: No author of this paper has a conflict of interest, including specific financial interests, relationships, and/or affiliations relevant to the subject matter or materials included in this manuscript.

Disclosure of funding: The authors have no conflicts of interest or funding to disclose.

\section{References}

1. Kaya Z, Muluk C, Haskoloğlu Ş, Lale Ş, Tufan LŞ. A novel mutation in a child with atypical Wiskott-Aldrich syndrome complicated by cytomegalovirus infection. Turk J Hematol 2019;36:70-71.

2. Ochs HD, Filipovich AH, Veys $P$, Cowan MJ, Kapoor N. Wiskott-Aldrich syndrome: diagnosis, clinical and laboratory manifestations, and treatment. Biol Blood Marrow Transplant 2009;15(1 Suppl):84-90.

3. Candotti F. Clinical manifestations and pathophysiological mechanisms of the Wiskott-Aldrich syndrome. J Clin Immunol 2018:38:13-27.

4. Notarangelo LD, Miao $\mathrm{CH}$, Ochs HD. Wiskott-Aldrich syndrome. Curr Opin Hematol 2008;15:30-36.

5. Zhu Q, Zhang M, Blaese RM, Derry JM, Junker A, Francke U, Chen SH, Ochs HD. The Wiskott-Aldrich syndrome and X-linked congenital thrombocytopenia are caused by mutations of the same gene. Blood 1995;86:3797-3804

6. Pelley JW. Elsevier's Integrated Biochemistry, 2nd ed. Amsterdam, Elsevier, 2007.

7. Du W, Kumaki S, Uchiyama T, Yachie A, Yeng Looi C, Kawai S, Minegishi M, Ramesh N, Geha RS, Sasahara Y, Tsuchiya S. A second-site mutation in the initiation codon of WAS (WASP) results in expansion of subsets of lymphocytes in a Wiskott-Aldrich syndrome patient. Hum Mutat 2006;27:370-375.

- Copyright 2020 by Turkish Society of Hematology

Turkish Journal of Hematology, Published by Galenos Publishing House 